\title{
A Pen inside the Maxillary Antrum: Report of a Case
}

\section{Javier Alexis Delgado1, Guillermo Bravo² and Jaime Castro-Nunez ${ }^{3 *}$}

${ }^{1}$ Doctor of Dental Surgery, Universidad de Antioquia, Oral and Maxillofacial Surgeon, Universidad El Bosque, Head of the Oral and Maxillofacial Surgery Department, Hospital Cardiovascular del Niño de Cundinamarca, Soacha, Cundinamarca, Colombia

${ }^{2}$ Doctor of Dental Surgery, Universidad El Bosque, Oral and Maxillofacial Surgeon, Universidad El Bosque, Private Practice, Bogotá, Cundinamarca, Colombia

${ }^{3}$ Doctor of Dental Surgery, Universidad de Antioquia, Oral and Maxillofacial Surgery Resident, Universidad El Bosque, Bogotá, Cundinamarca, Colombia

\begin{abstract}
Foreign bodies in the antrum of Highmore are uncommon, rarely seen entities, being the mouth the most frequent route of entry, especially during dental procedures. Other paths include the cheek, nose and lower ayelid. In the case we report here, a pen gained access to the maxillary antrum through the lower eyelid. A 13-year-old male patient presented to the Oral and Maxillofacial Surgery Department at Hospital Cardiovascular del Niño de Cundinamarca in Soacha, Colombia, with the chief complaint of a broken pen inside the right maxillary antrum. The surgical management of the case and sequelae are described.
\end{abstract}

Keywords: Maxillary antrum; Foreign body

\section{Introduction}

The maxillary sinus (antrum) is also known as the antrum of Highmore, is a paired air-filled space located largely in the body of each maxilla surrounding the nose. It is pyramidal in shape and it is composed of a roof and a floor, and three walls: posterolateral, facial and medial (base). The roof is thin and extends laterally as far as the inferior orbital fissure. The floor is formed by the lower third of the base and the buccoalveolar wall. The posterolateral wall is the anterior limit of the pterygopalatine fossa and the pterygomaxillary fissure. The facial wall forms the anterior aspect of the sinus and the medial wall is formed by the lateral wall of the nose and the palatal alveolar process of the maxilla [1].

First described in 1489 by Leonardo da Vinci and later by Vesalius (1543) and Nathaniel Highmore in his Corporis Humani Disquisitio Anatomica in 1651, the maxillary sinus has ostia that open high up through the base into the middle meatus of the nose. It is approximately $35 \mathrm{~mm}$ in height, $32 \mathrm{~mm}$ anteroposteriorly, $25 \mathrm{~mm}$ in width with a mean volume of $15 \mathrm{ml} \mathrm{[2].} \mathrm{It} \mathrm{is} \mathrm{lined} \mathrm{by} \mathrm{pseudostratified,} \mathrm{ciliated} \mathrm{columnar}$ epithelium which contains mucus-secreting goblet cells. Each epithelial cell has around 200 cilia that project from its free surface beating at a frequency of $15 \mathrm{~Hz}$ at body temperature [1].

Foreign bodies in the maxillary antrum are unusual, rarely seen entities [3]. The most common route of entry is the mouth during dental procedures or via an oroantral communication that remains as a fistula. Other paths include the cheek, nose and lower eyelid [4-6]. In

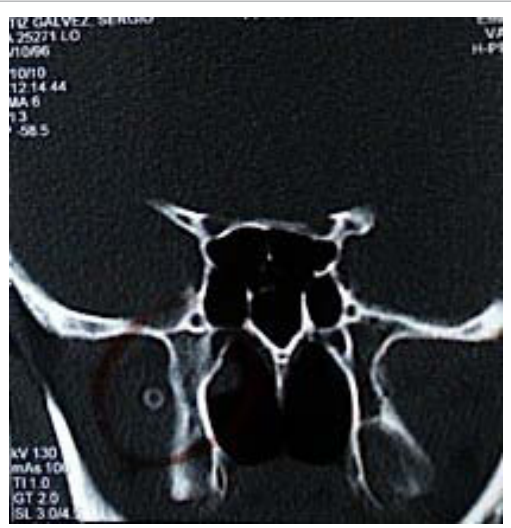

Figure 1: CT showing foreign body into the maxillary sinus. the case we report here, a pen gained access to the maxillary antrum through the lower eyelid.

\section{Case report}

A 13-year-old male patient enters the Oral and Maxillofacial Surgery Department at Hospital Cardiovascular del Niño de Cundinamarca in Soacha, Cundinamarca, Colombia, twelve months after an accidental introduction of a broken pen into the right maxillary antrum. The adolescent, who had in his right hand a 5.5 -inch pen, was being chased by his older sister and while escaping from her, he suddenly went down and the point of the pen, which faced him during the fell, perforated the conjunctiva and fractured the floor of the orbit. Half of the pen entered the antrum, while the other half broke and remained outside. The perforation was clean, leaving neither bleeding nor scars in his eye.

Afraid of their mother, the siblings decided not to report the casualty. Twelve months after the injury the eye's upper movements were limited and painful. Therefore, the boy decided to report the misshapen to the mother, who immediately took him to the Hospital Cardiovascular del Niño de Cundinamarca, where he was referred to the Oral and Maxillofacial Surgery Department.

Enquiry into the patient's medical history revealed he was a healthy person not taking any medicines at the time of the appointment. At physical examination, the only sign worth noting was an evident limitation of the upper movement of the right eye. When asking the patient to look up, the left eye would move within the normal limits, while the right one barely moved. A computed Tomography (CT) scan was ordered and it confirmed the presence of a large foreign body in the right maxillary antrum located between the anterior wall and the pterygomaxillary junction. There was a thickening of the sinus lining. A fracture of the orbital floor was identified (Figure 1). Two days later

*Corresponding author: Jaime Castro-Núñez, Doctor of Dental Surgery, Universidad de Antioquia, Oral and Maxillofacial Surgery Resident, Universidad E Bosque, Bogotá, Cundinamarca, Colombia, Calle 131 \#19-73 Apto 205, Bogotá Colombia, South America, Tel: 300-4990431; E-mail: jacastron@hotmail.com

Received April 03, 2012; Accepted June 05, 2012; Published June 12, 2012

Citation: Delgado JA, Bravo G, Castro-Nunez J (2012) A Pen inside the Maxillary Antrum: Report of a Case. Dentistry 2:138. doi:10.4172/2161-1122.1000138

Copyright: (c) 2012 Delgado JA, et al. This is an open-access article distributed under the terms of the Creative Commons Attribution License, which permits unrestricted use, distribution, and reproduction in any medium, provided the original author and source are credited. 


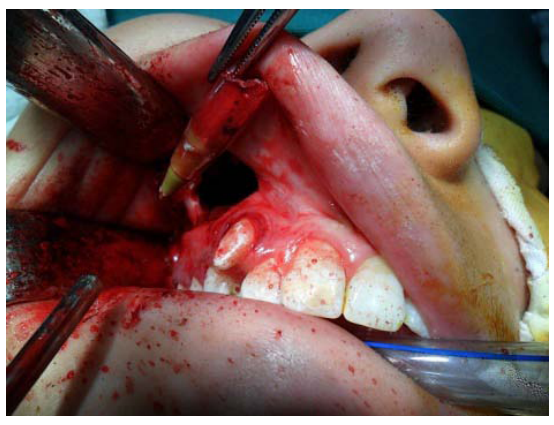

Figure 2: Foreign body being retrieved after a Caldwell-Luc approach.

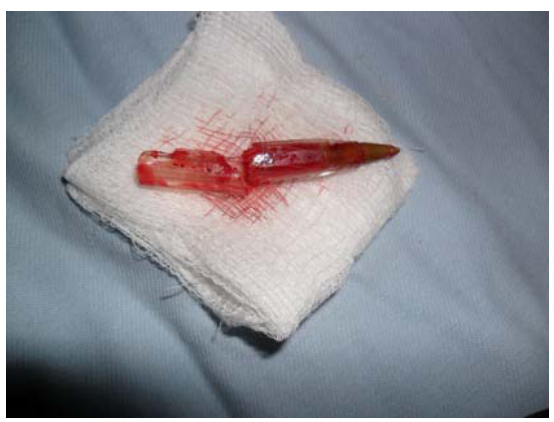

Figure 3: Pen retrieved from the maxillary sinus.

the patient was scheduled for removal of the broken pen and reduction of the orbital fracture.

Under general anesthesia an external approach using the CaldwellLuc technique was performed in order to gain access to the outer wall of the right maxillary antrum. The broken pen was visualized and retrieved (Figure 2,3). Due to the presence of a serious retention cyst, an enucleation of the sinus lining was performed. The maxillary sinus was irrigated, the window closed with the periosteum and soft tissues repositioned and sutured with 3/0 Vicryl Ethicon (Figure 4). In order to reduce the fracture of the floor of the orbit, a transconjunctival approach was performed, the osseous surface visualized, the fracture reduced with a $3 \times 4 \mathrm{~cm}$ titanium micro mesh, fixed with three 1.5 selfdrilling screws (Tekka) and the soft tissues repositioned. The fornix was not sutured.

Upon finishing the procedure, the patient was sent to the recovery room for two hours and returned home thereafter. A tablet of 500 mg of Cephalexin every six hours for ten days was prescribed. The following day the patient returned with a post-operative radiograph, which confirmed that the sinus was clean and the fracture correctly reduced. A post-operative follow-up ten days later revealed the surgical site was healing satisfactorily. His right eye, which had virtually no motion up before surgery, now started to move and follow the left one, even though an evident damage of the inferior rectus muscle was seen (Figure 5). The patient was sent to the Ophthalmology Department, where an oculoplastic surgeon currently manages the case.

\section{Discussion}

Foreign bodies can get into the maxillary sinus mainly due to trauma and accidents during dental or surgical treatment (iatrogenic). Other mechanisms of penetration, such as self-inflicted, have been reported [7]. The reason most foreign bodies lodge into the maxillary sinus at the dental office is because the bone of the maxillary sinus floor is very thin and in some persons the roots of the molars project through this bone $[1,8]$. Therefore, not only dentists but also dental assistants must be very careful while performing work around this area [8]. In 1978 Lee found that the roots of the upper first molar were most often displaced, with the palatal root accounting for the $76 \%$ of all displaced roots [9].

The scientific literature reveals that among the foreign bodies found in the maxillary sinus are dental burs [3], roots of teeth [4], amalgam [4], titanium implants [4,10], glass [4], impression dental materials [8], sand [11] bullets [12] and gutta-percha points [13]. Less found bodies include stones, matchsticks, wood [14] and many others [15-18]. The possibility of displacing a dental root to the maxillary sinus during surgical procedures in the oral cavity has been recognized since 1858 when Cattlin [18] reported a dislodged root into the antrum.

There are two surgical approaches to the maxillary sinus: through the site of the tooth socket or through the canine fossa by using the Caldwell-Luc approach, where an incision is made in the buccal sulcus from the lateral incisor to the first molar. A mucoperiostal flap is then raised and retracted and a window made into the sinus through the bone of the canine fossa [1]. Opportune surgical retrieval of the foreign body is desirable in order to prevent the possible sequelae of sinusitis and infection $[5,6]$.

The case we report here has two distinctive facts: time and type of foreign body. The literature advocates for a prompt retrieval of foreign bodies in the maxillary sinus, but in our case it remained inside the antrum during twelve months and with no clinical symptoms. The type of the foreign body, on the other hand, revealed a $5 \mathrm{~cm}$ broken plastic pen.

\section{Conclusion}

In the case reported the patient remained with a foreign body inside

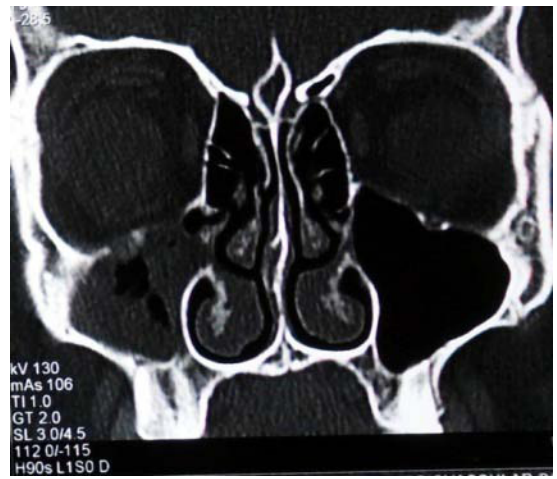

Figure 4: POP CT scan.

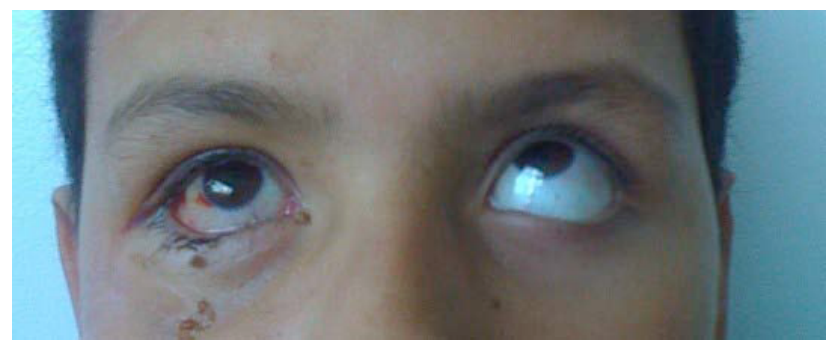

Figure 5: When asked to look up, the right eye would not follow the left one. 
Citation: Delgado JA, Bravo G, Castro-Nunez J (2012) A Pen inside the Maxillary Antrum: Report of a Case. Dentistry 2:138. doi:10.4172/21611122.1000138

the maxillary antrum for twelve months. The foreign body was retrieved under general anesthesia by way of a Caldwell-Luc approach. The surgical procedure had no complications; the patient was discharged, followed up on an out-patient basis and referred to the oculoplastic surgeon for treatment of hypotrophy of the inferior rectus muscle.

\section{Acknowledgments}

The authors would like to thank Mrs Kathryn Pope at Antioch University, Los Angeles, CA for her assistance in the preparation of this paper.

\section{References}

1. McGowan D, Baxter PW, James J (1993) The maxillary sinus. First edn, Butterworth-Heinemann Ltd, Oxford.

2. Neivert $H$ (1930) Surgical anatomy of the maxillary sinus. Laryngoscope 40 : $1-4$.

3. Abe K, Beppu K, Shinohara M, Oka M (1992) An iatrogenic foreign body (dental bur) in the maxillary antrum: a report of two cases. Br Dent J 173: 63-65.

4. Bodet Agustí E, Viza Puiggrós I, Romeu Figuerola C, Martinez Vecina V (2009) [Foreign bodies in maxillary sinus]. Acta Otorrinolaringol Esp 60: 190-193.

5. Clayman GL, Adams GL, Paugh DR, Koopmann CF Jr (1991) Intracranial complications of paranasal sinusitis: a combined institutional review. Laryngoscope 101: 234-239.

6. De Foer C, Fossion E, Vaillant JM (1990) Sinus aspergillosis. J Craniomaxillofac Surg 18: 33-40.
7. Lima MM, Moreira CA, Silva VC, Freitas MR (2008) 34 self-inflicted foreign bodies in the maxillary sinus. Braz J Otorhinolaryngol 74: 948.

8. Dimitrakopoulos I, Papadaki M (2008) Foreign body in the maxillary sinus: report of an unusual case. Quintessence Int 39: 698-701.

9. Lee FM (1978) Management of the displaced root in the maxillary sinus. Int $J$ Oral Surg 7: 374-379.

10. lida S, Tanaka N, Kogo M, Matsuya T (2000) Migration of a dental implant into the maxillary sinus. A case report. Int J Oral Maxillofac Surg 29: 358-359.

11. Dunagan DP, Cox JE, Chang MC, Haponik EF (1997) Sand aspiration with near-drowning. Radiographic and bronchoscopic findings. Am J Respir Crit Care Med 156: 292-295.

12. KOZLOWSKI K, LAJP B (1964) Metallic foreign body in the maxillary sinus Lancet 2: 698.

13. Liston PN, Walters RF (2002) Foreign bodies in the maxillary antrum: a case report. Aust Dent J 47: 344-346.

14. Rahman A (1982) Foreign bodies in the maxillary antrum. Br Dent J 153: 308.

15. Gupta AC, Murthy DP, Pulotu ML (1990) Unusual type of foreign body in the maxillary sinus. J Laryngol Otol 104: 718-719.

16. Sims AP (1985) A dental root in the ostium of the maxillary antrum. Br J Ora Maxillofac Surg 23: 67-73.

17. Smith JL 2nd, Emko P (2007) Management of a maxillary sinus foreign body (dental bur). Ear Nose Throat J 86: 677-678.

18. Cattlin W (1858) Peculiarities of the interior of the antrum; case in which a fang of a tooth was impacted in a pocket of the antrum. BMJ June, 1858:485 